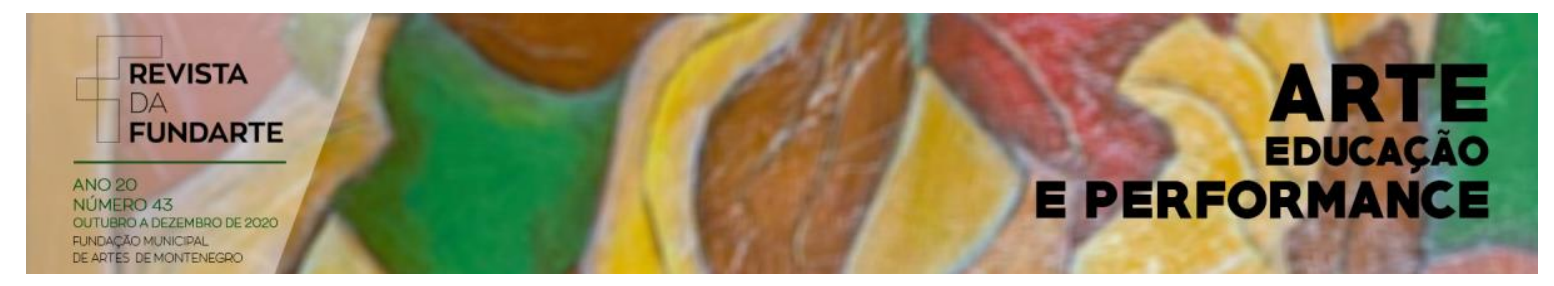

\title{
MAS AONDE FOI PARAR A SANTA DO SERTÃO, MARIA SALDANHA?: PROCURA INCESSANTE POR FIGURAS FEMININAS QUE ACAMPAM UM ÍNTIMO/MUNDO IMENSAMENTE POVOADO
}

\author{
João Vítor Ferreira Nunes
}

DOI: $\underline{\text { http://dx.doi.org/10.19179/2F2319-0868/2F758 }}$

NUNES, João Vítor Ferreira. Mas aonde foi parar a santa do sertão, Maria Saldanha?: procura incessante por figuras femininas que acampam um íntimo/mundo imensamente povoado. Revista da FUNDARTE. Montenegro, p.01-15, ano 24, no 43, outubro/dezembro de 2020.

Disponível em: http://.seer.fundarte.rs.gov.br/index.php/revistadafundarte/index $>20$ de dezembro de 2020. 


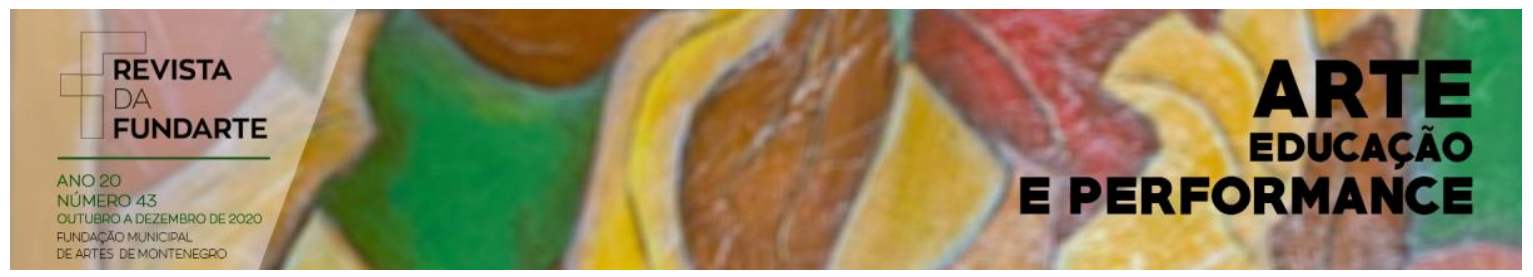

\title{
MAS AONDE FOI PARAR A SANTA DO SERTÃO, MARIA SALDANHA?: PROCURA INCESSANTE POR FIGURAS FEMININAS QUE ACAMPAM UM ÍNTIMO/MUNDO IMENSAMENTE POVOADO
}

João Vítor Ferreira Nunes ${ }^{1}$

Resumo: No século XX, em meio ao sertão nordestino, eis que existiu uma flor que brotou e se adaptou à seca da região, chamada Maria Saldanha, e que logo fora reconhecida como uma mulher Santa. Ocupando um lugar de escuta entre gerações, desancorei da memória das mulheres de minha família Mulato uma história feminina, cujos ritos remontam significativos episódios de ruptura com a educação padrão imposta para os sexos. Eis aqui uma pesquisa que, rapidamente, afinou laços entre parentescos e desaguou em comunicações pelas vias da fala/performance ao realizar uma busca incessante pela figura da Santa do Sertão, Maria Saldanha, cuja mulher destemida sumiu no mundo ao ser humilhada e expulsa de várias terras por ir contra o patriarcado.

Palavras-chave: Energia Ânima; Jornada Artetnográfica; Ritos de Passagem.

\section{WHERE DID THE SAINT OF THE BACKWOODS, MARIA SALDANHA, GO? CONTINUOUS SEARCH FOR FEMALE FIGURES THAT ARE ESTABLISHED IN AN INTIMATE/WORLD DENSELY INHABITED}

\begin{abstract}
During the 20th century, the northeastern backwoonds witnessed the growth and adaptation to drought of a flower known as Maria Saldanha, who was soon recognized as a saint. Acting as a listener among different generations, I dug into the memory of the women of my family Mulato and unveiled memories concerning female history, whose rites refer to episodes of significant break with the standard sexist education. Here is a study that quickly sharpened ties between kinships and uncovered scenic communication through speech / performance by conducting an incessant search for the figure of Saint of the Backwoods, Maria Saldanha, whose woman disappeared into the world when she was humiliated and expelled from various lands for going against patriarchy.
\end{abstract}

Keywords: Anima-Energy; Artethnographic Journey; Rites of Passage

Ocupando um lugar de escuta entre gerações, desancorei do imaginário de Bia Mulato parte de seus ritos de passagem através de uma pesquisa de campo

\footnotetext{
1 João Vítor Mulato é artista-docente em formação. Doutoranda em Teatro no PPGT da UDESC, sob orientação das Drª̂s. Maria Brígida de Miranda e Sandra Meyer Nunes. Mestra pelo PPGArC da UFRN e Graduada em Teatro pela mesma instituição. Formada em Pedagoga pela UNINASSAU. Possui experiências teórico-práticas com as linguagens da Dança, Teatro e Performance, chegando a comunicações pelas vias da fala/cena. E-mail: joaovitormulatto@gmail.com
}

NUNES, João Vítor Ferreira. Mas aonde foi parar a santa do sertão, Maria Saldanha?: procura incessante por figuras femininas que acampam um íntimo/mundo imensamente povoado. Revista da FUNDARTE. Montenegro, p.01-15, ano 24, oㅡ 43, outubro/dezembro de 2020.

Disponível em: http://.seer.fundarte.rs.gov.br/index.php/revistadafundarte/index $>20$ de dezembro de 2020. 


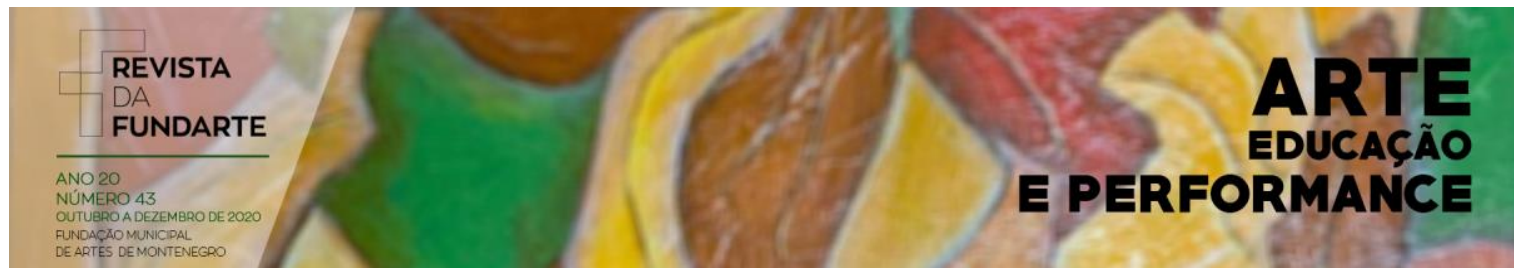

intitulada de Artetnográfica, conceito este cunhado pela artista, pesquisadora e feminista, Luciana Lyra (UERJ). Faz-se mister apontar que essa relação entre o pesquisador e a alteridade é, em resumo,

[...] a fase do primeiro exercício hermenêutico propriamente dito, o cruzamento de experiências, de permuta com o contexto de alteridade nas suas diversas dimensões, estabelecendo vínculos e vivenciando seu cotidiano e suas ações estéticas em troca de vivências artísticas. Estimuladas pelos artistas em campo. Durante esta fase processual, investe-se em toda sorte de mídias de registro da experiência, desde escritos em livros de artista a imagens gravadas ou filmografadas, sem compromisso com a linearidade espaço-temporal, a exemplo das experiências surrealistas. (NUNES, 2019, p. 17 apud LYRA, 2015, p. 40).

Ao longo dessa jornada que ocorreu em campo, pude constatar que o Nordeste em si é um espaço mágico, cheio de surpresas e nada esotérico como pensam. Somos capazes de compreender seus fatos e narrativas peculiares quando chegamos a determinados solos, ao vivenciar o cotidiano das pessoas, sobretudo aquelas contadoras de histórias. Entretanto, o sertão nordestino é um espaço místico, e tais mistérios rondam os pequenos povoados, seus lares e até mesmo as flores.

Ao longo da pesquisa, me deparei com os ritos do filho de Zé Videira, que em noite de lua cheia virava bicho na região, com os relatos do coro de vozes das pessoas que foram covardemente escravizadas e mortas no enorme canavial e engenho, bem como com a história da casa da Dona Maria Ferrer que, os visitantes, ao entrarem em seu lar, eram expulsos pelos espíritos que com ela residiam, onde ficavam bravos e começavam a derrubar parte dos móveis, como se um vendaval tomasse conta do espaço. É a partir dessas narrativas suplantadas no imaginário social que reafirmo que o sertão é um lugar místico, quase transcendental, que ultrapassa às leis físicas humanas. E quem de nós pode dizer que todas essas narrativas do povo sertanejo são fantasiosas? Porém, não escrevi esse artigo para falar sobre a vida do menino monstro, nem do coro dos escravizados e nem tão pouco dos espíritos amigos da Dona Maria Ferrer; não que essas histórias não despertem em mim um amplo interesse, mas escrevi para falar sobre a Santa do

NUNES, João Vítor Ferreira. Mas aonde foi parar a santa do sertão, Maria Saldanha?: procura incessante por figuras femininas que acampam um íntimo/mundo imensamente povoado. Revista da FUNDARTE. Montenegro, p.01-15, ano 24, no 43, outubro/dezembro de 2020.

Disponível em: http://.seer.fundarte.rs.gov.br/index.php/revistadafundarte/index> 20 de dezembro de 2020. 


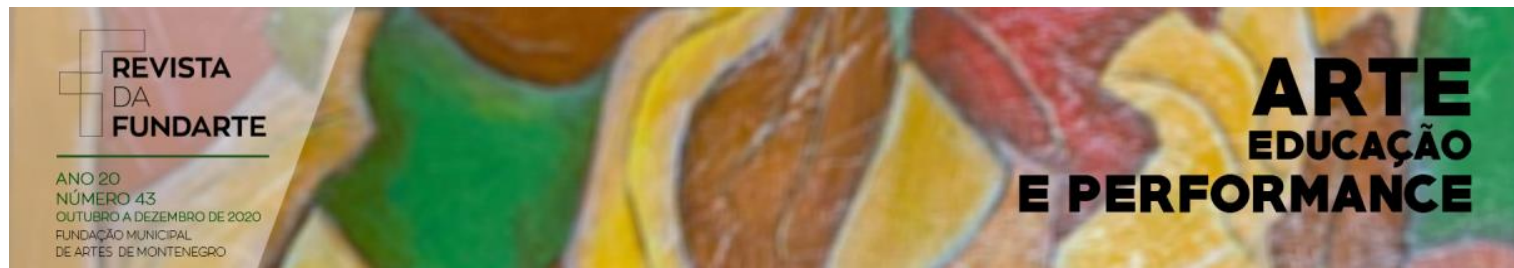

Sertão, Maria Saldanha, mulher que fora por muitos anos a grande amiga de Bia Mulato.

Mareja Bia os olhos ao se/me perguntar aonde foi parar a mulher considerada a Santa do Sertão, e esse foi o grande motivo de eu ter rumado para a região, berço nascente das/os Mulatos. Parti para o sertão Potiguar, mais precisamente para Sítio do Angico, pequeno povoado localizado no interior de José da Penha, Rio Grande do Norte $(\mathrm{RN})$, com dois objetivos, sendo o primeiro deles, a busca por notícias de Maria, e o segundo, por materiais que viessem a me incitar nas salas de ensaio, pois eu tinha a intenção de trazer para meu corpo a figura da mulher Santa, via processos artísticos de carnificações, fazendo assim uma amálgama entre a história de Maria Saldanha e minha dimensão feminina interior; ânima, que segundo o psiquiatra Carl Gustav Jung (2000), é o lado feminino oculto que há no íntimo dos homens. Contudo, antes de nos aprofundarmos nos entendimentos da ânima, serpentearemos entre os ritos da mulher santa.

\section{NOS RASTOS DA SANTA DO SERTÃO, MARIA SALDANHA}

De 2017 a 2019, descobri que Maria foi flor que brotou e se adaptou a seca do sertão nordestino, vivendo sua infância e parte de sua juventude, na fronteira entre o Rio Grande do Norte $(R N)$ e a Paraíba $(P B)$, em um pequeno interior chamado de Catolé do Rocha. Mas foi em Sítio do Angico, RN, que Maria foi posta em um pedestal, e lá também fora o local onde ocorreu o primeiro encontro entre ela e Bia. Mas, antes que se tornasse a mentora de uma criança em vida, ela foi menina e, por ter nascido mulher, passou por episódios de humilhação em seu próprio seio familiar. $\mathrm{Na}$ intenção de utilizar uns exemplos acerca dos tratamentos que as meninas recebem em comparação aos meninos, insiro nesse estudo uma breve citação do antropólogo britânico Victor Turner, a partir de seu livro Florestas dos Símbolos (2005), aonde ele nos diz que:

NUNES, João Vítor Ferreira. Mas aonde foi parar a santa do sertão, Maria Saldanha?: procura incessante por figuras femininas que acampam um íntimo/mundo imensamente povoado. Revista da FUNDARTE. Montenegro, p.01-15, ano 24, no 43, outubro/dezembro de 2020.

Disponível em: http://.seer.fundarte.rs.gov.br/index.php/revistadafundarte/index $>20$ de dezembro de 2020. 


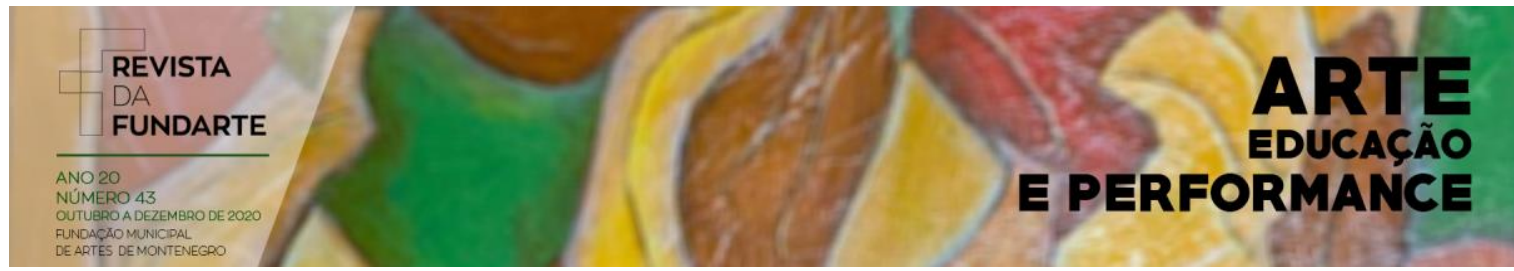

Embora tanto os meninos quanto as meninas passem por cerimônias de iniciação, a forma e o propósito das cerimônias diferem enormemente em cada caso. Os meninos são iniciados coletivamente; as meninas, individualmente. Os meninos são iniciados antes da puberdade; as meninas, logo no início da mesma. O principal objetivo da iniciação dos meninos é inculcar-Ihes valores tribais, habilidades da caça e instrução sexual; o da iniciação das meninas é prepará-las para o casamento, que, na maioria dos casos, se segue imediatamente a esta iniciação. Os meninos são isolados e ensinados na floresta; uma cabana de palha é construída na própria aldeia para as meninas. Os principais pontos a serem notados, no entanto, são: o contraste entre a natureza coletiva da cerimônia dos meninos com o tratamento individual dado às meninas; a ênfase na obediência à disciplina dos anciões e em suportar provas duras e difíceis para os meninos, em contraste com a ênfase no sexo e na reprodução e a libertação do trabalho manual, associados com a cerimônia das meninas; o contexto da floresta para a cerimônia dos meninos, contrastando com o contexto doméstico e aldeão daquela das meninas. (TURNER, 2005, p. 36).

Por meio dos escrito de Turner, podemos observar que há uma discrepante diferença entre a educação dada para os meninos e para as meninas, como por exemplo, enquanto eles eram ensinados a colocarem em prática sua virilidade e independência por meio de rituais voltados à caça, as meninas eram postas em uma cabana para serem treinadas para o casamento, a fim aprenderem a agradar 0 suposto cônjuge. A vida de Maria Saldanha não foi diferente, pois, da infância a juventude, foi obrigada a aprender com sua mãe a como cuidar de todo o lar, para que, quando os homens chegassem, tendo em vista que estavam cuidando das terras e animais, a encontrassem toda organizada, sem poeiras e defeitos. Além da assoladora obrigação de manter o lar em ordem para aqueles que se consideravam o eixo da residência, Maria era obrigada a frequentar as missas que aconteciam em Catolé do Rocha (PB), uma vez que havia nascido em um lar rigorosamente religioso. Quase todos os dias, junto de sua mãe, a menina estava na igreja e, em decorrência a sua assiduidade, seu pai - sujeito que o povo de Sítio do Angico desconheciam o nome -, decidiu que logo mais a colocaria em um convento, a fim de ver sua filha uma freira quando atingisse seus dezoito anos de idade, e essa decisão foi tomada pelo mesmo, sem o seu consentimento. E assim Maria cresceu,

NUNES, João Vítor Ferreira. Mas aonde foi parar a santa do sertão, Maria Saldanha?: procura incessante por figuras femininas que acampam um íntimo/mundo imensamente povoado. Revista da FUNDARTE. Montenegro, p.01-15, ano 24, № 43, outubro/dezembro de 2020.

Disponível em: http://.seer.fundarte.rs.gov.br/index.php/revistadafundarte/index $>20$ de dezembro de 2020. 


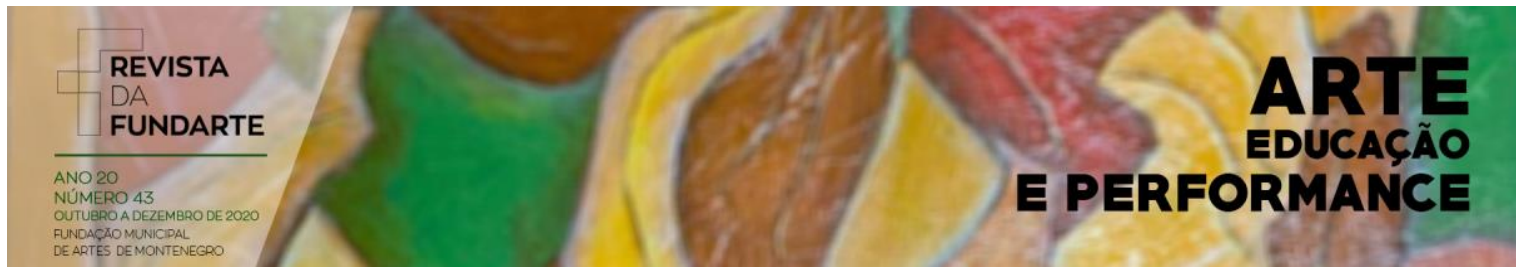

sendo "domesticada2" em seu lar, frequentando às missas diariamente, para que se tornasse uma mulher pura, digna de respeito - na visão dos conservadores.

Após descobrir esse rito que ocorreu com Maria Saldanha, passei a me perguntar as seguintes coisas: por quais motivos desejam que algumas vidas femininas estejam diretamente ligadas à religiosidade e/ou a condução de uma casa? Por que querem prender mulheres em alguns lares em nome de Deus, sem que elas tenham o direito de escolha? Mas, talvez a grande pergunta seja: por quais motivos sempre há homens à frente das mulheres, fazendo escolhas por elas? $\mathrm{O}$ que de fato eles temem? Dá-me a impressão de que esses tipos de sujeitos acham que as mulheres não devem possuir direito de escolha, considerando-as sem discernimento suficiente para decidir por si própria. Aquilo que os homens machistas e misóginos fazem me deixa imensamente triste, mas o que querem nos impedir de fazer ou de ser, me deixa irreversivelmente furiosa (NUNES, 2019, apud DESPENTES, 2016).

Quando se tornou moça, Maria começou a desfrutar, por conta própria, de situações que a desviava (in)diretamente dos caminhos escolhidos pelo seu pai, e foi através desses atos que percebeu que a vida ligada à religião católica não era a que gostaria de seguir. Logo, guiada por uma força mística, e também por tambores, se atraiu por uma religião de matriz africana, a qual a fazia se sentir completa consigo mesma. Para poder frequentar os rituais, ela saía de casa dizendo que ia à missa, mas, rapidamente, tomava novos rumos e chegava, sem volver, na residência que ocorriam às manifestações. Em seu $\| \hat{e}^{3}$, aprendeu a evocar, engrandecer e manifestar os representantes da força da natureza, os Orixás.

No período da colonização, um mar de gente começou a acreditar que a religião católica; vista por mim como de origem branca: fé branca, era a mais apropriada a ser seguida, enquanto as demais crenças foram e são demonizadas,

\footnotetext{
${ }^{2}$ Ao longo a pesquisa de campo realizada, ouvia dos homens que as mulheres eram domesticadas no passado.

${ }^{3}$ Casas de candomblé ou terreiros que ocorrem festividades que enaltecem a cultura e divindades Africanas.
}

NUNES, João Vítor Ferreira. Mas aonde foi parar a santa do sertão, Maria Saldanha?: procura incessante por figuras femininas que acampam um íntimo/mundo imensamente povoado. Revista da FUNDARTE. Montenegro, p.01-15, ano 24, no 43, outubro/dezembro de 2020.

Disponível em: http://.seer.fundarte.rs.gov.br/index.php/revistadafundarte/index $>20$ de dezembro de 2020. 
tal como a seguida por Maria Saldanha em sua juventude. Apesar da marginalização de sua religião, a moça sentia-se forte ao frequentar a casa, entretanto sua presença era tocaiada, uma vez que seus familiares afirmavam, frequentemente, que a religião não deveria ser seguida pelos entes, nem tão pouco passar na frente da casa. Pobres ignorantes, não sabiam que Maria Saldanha não só passava na frente do lar, como também entrava, dançava, respeitava e idolatrava seus antepassados.

Como sua terra natal, Catolé do Rocha, não era suficientemente grande, Maria Saldanha pediu encarecidamente às outras amigas de fé religiosa que nada contassem ao povo de sua casa sobre a sua participação nos rituais sagrados. $E$ assim fizeram, mantendo tudo em segredo. Enquanto pôde, Maria levou sua vida dividida entre duas religiões; uma que seus pais haviam escolhido para ela ainda na infância, e a outra, a qual, ela sentia-se atraída pelos sons ecoados que saiam dos tambores, tocando à fundo seu coração. Sua presença naquele llê tinha tempo determinado. Seu pai, certa vez, a seguiu e descobriu sua assiduidade na casa, e logo veio o seu primeiro castigo físico sofrido; a agressão ao seu corpo e a prisão em seu lar. Mas, antes de seguirmos nos ritos de Maria, faço um pedido: "parem de querer nos convencer que a violência contra as mulheres é um fenômeno recente ou próprio de um grupo específico" (DESPENTES, 2016, p. 30), pois, no fundo, "a agressão ao corpo da mulher é uma agressão de longo alcance que atinge, tanto os que vieram antes dela quanto os que chegarão depois" (ESTES, 1994ª p. 151).

Em Vigiar e Punir (1987), Michel Foucault nos fala sobre o Teatro dos Castigos, apresentando-nos às técnicas de poder utilizadas para controlar os corpos de quem ousassem cometer algo que fosse julgado como errado. $E$ tal meio de dominação acontecia nas praças públicas, para que todos vissem e não viessem a passar por cima das leis impostas. Com isso, a pessoa que sofria a punição era utilizada como modelo negativo para a sociedade. Partindo dessa perspectiva, visualizo que embora esses episódios tenham ocorrido não em solos nordestinos, mas ainda assim foi utilizado pelo pai de Maria Saldanha, para que ela não viesse a ousar ser livre, visto por mim esse tipo de dominação, como algo inerente em alguns

NUNES, João Vítor Ferreira. Mas aonde foi parar a santa do sertão, Maria Saldanha?: procura incessante por figuras femininas que acampam um íntimo/mundo imensamente povoado. Revista da FUNDARTE. Montenegro, p.01-15, ano 24, no 43, outubro/dezembro de 2020.

Disponível em: http://.seer.fundarte.rs.gov.br/index.php/revistadafundarte/index $>20$ de dezembro de 2020. 


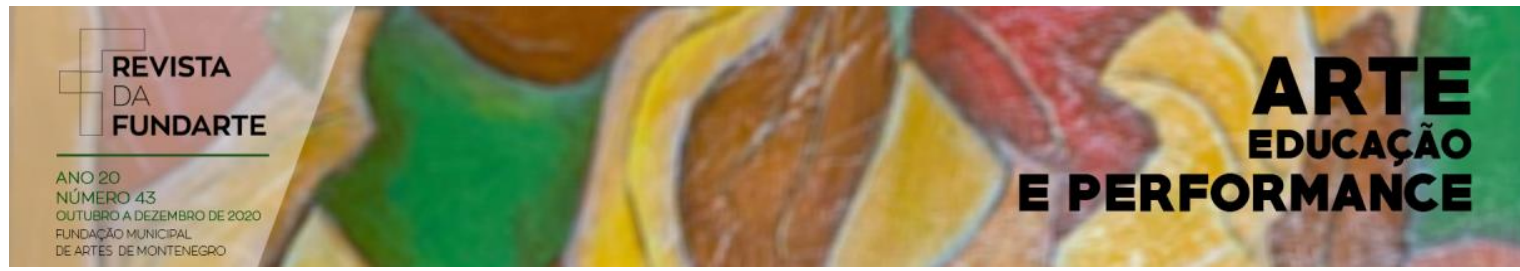

homens, sobretudo misóginos. Acerca de uma das milhares de técnicas explanadas por Foucault em seu livro, integro a esse artigo a seguinte, contida no livro:

[...] a prisão, a reclusão, os trabalhos forçados, a servidão de forçados, a interdição de domicílio, a deportação - que parte tão importante tiveram nos sistemas penais modernos - são penas "físicas": com exceção da multa, se referem diretamente ao corpo. Mas a relação castigo-corpo não é idêntica ao que ela era nos suplícios. O corpo encontra-se aí em posição de instrumento ou de intermediário; qualquer intervenção sobre ele pelo enclausuramento, pelo trabalho obrigatório visa privar o indivíduo de sua liberdade considerada, ao mesmo tempo, como um direito e como um bem. Segundo essa penalidade, o corpo é colocado num sistema de coação e de privação, de obrigações e de interdições. O sofrimento físico, a dor do corpo não são mais os elementos constitutivos da pena. O castigo passou de uma arte das sensações insuportáveis a uma economia dos direitos suspensos. Se a justiça ainda tiver que manipular e tocar o corpo dos justiçáveis, tal se fará à distância, propriamente, segundo regras rígidas e visando a um objetivo bem mais "elevado".(FOUCAULT,1987, p. 15).

Concomitante ao nefasto episódio de agressão e aprisionamento, seu pai contratou um sujeito para lhe vigiar aonde fosse. No mais tardar, aquele capataz encantou-se pela moça, quando ela começou a fazer uso de algumas técnicas de poder atrelada a sedução, e tudo na intenção de fazer com que ele a levasse ao llê. Ou seja, Maria o encantou para tirar proveito da situação, sendo ele apenas coadjuvante nessa empreitada, voltada a fé e resistência feminina. O jagunço do pai de Maria Saldanha não se tornou apenas seu cúmplice, mas também seu primeiro amor. Como no sertão haviam leis entre os patrões e os capatazes, o sujeito que foi contratado para vigiar Maria, sentiu a necessidade de partilhar com seu superior 0 suposto romance com a moça, no entanto, aquele que pagava por seus serviços não aceitou, de forma alguma, a relação amorosa do casal, visto que gostaria de inserir Maria brevemente num convento.

Ao longo da pesquisa de campo, descobri que Maria Saldanha sempre foi boa o suficiente para quebrar regras e, dentre elas, a não aceitação do destino que seu pai teria escolhido para ela. Com isso, a moça do sertão começou a frequentar novos estabelecimentos, sem que seu pai permitisse, contudo, ela sempre fez questão de que todos soubessem, principalmente ele. Bradavam que as mulheres

NUNES, João Vítor Ferreira. Mas aonde foi parar a santa do sertão, Maria Saldanha?: procura incessante por figuras femininas que acampam um íntimo/mundo imensamente povoado. Revista da FUNDARTE. Montenegro, p.01-15, ano 24, no 43, outubro/dezembro de 2020.

Disponível em: http://.seer.fundarte.rs.gov.br/index.php/revistadafundarte/index $>20$ de dezembro de 2020. 


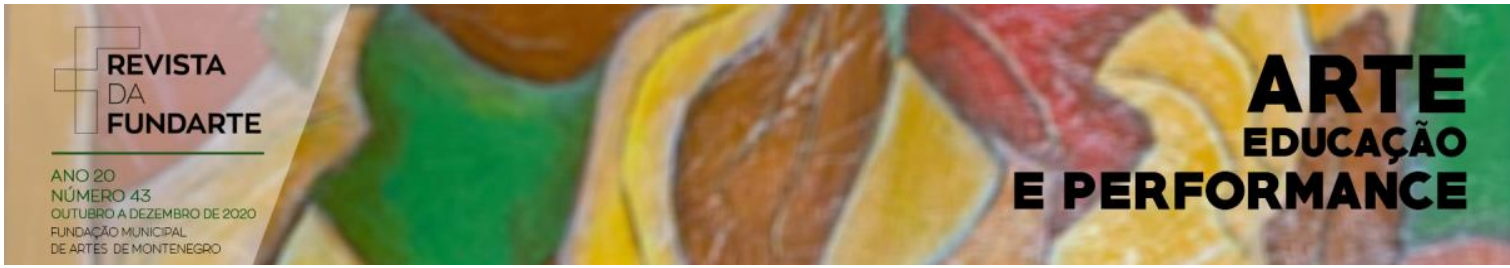

não deveriam adentrar nesses espaços, visto que eram as rodas de dança e seus bares, assim como as casas de Umbanda/llê. E devido seus feitos, mais uma vez o seu pai a agrediu na frente de toda vizinhança. Após a agressão, uma revolta fora sendo alimentada no coração da destemida Maria e, começou ela, a se rebelar ainda mais, passando a namorar nas praças, a fugir de casa durante a noite, passando dias mundo afora, bebendo e tomando banhos em rios, açudes e lagos, completamente despida. Plausível Maria, ela vivia como se não houvesse amanhã, movida por sua fúria e desejos em pleno sertão paraibano.

Quando uma pessoa vive de verdade, todos os outros também vivem. E todos os animais, nós incluídas, por meros momentos, voltávamos a ser selvagens. [...] quando uma criatura resolve se dedicar a viver do modo mais pleno possível, muitas outras que estiverem por perto se - deixarão contagiar. Apesar das barreiras, do confinamento, até mesmo de lesões, se alguém se determinar a superar tudo para viver plenamente, a partir daí outros também o farão, e esses outros incluem filhos, companheiros, amigos, colegas de trabalho, desconhecidos, animais, e flores. - Quando uma pessoa vive de verdade, todos os outros também vivem. Esse é o principal imperativo da mulher sábia. Viver para que outros também se inspirem. Viver do nosso próprio jeito vibrante para que outros aprendam conosco. (ESTES, $2007^{\text {b }}$, p. 16).

Tenho visto o quão alguns homens têm medo de mulheres com atitudes e, como Maria Saldanha era uma dessas mulheres, que passava por cima das autoridades, rapidamente foi expulsa de seu berço por seus familiares. No ato da expulsão, carregava em seu ventre uma criança, contudo não sabia da gestação, e esse foi seu primeiro rito de separação sofrido em Catolé do Rocha, Paraíba. Parto da perspectiva de falar sobre os Ritos de Separação, a partir do antropólogo Arnold van Gennep (2011), o qual afirma que a separação pode ocorrer de modo espontâneo ou forçoso e que, após ocorrer um rito de separação, outros ritos hão de surgir mais adiante, sendo eles situações cíclicas, que se renovam e se espraiam, sendo mais precisamente os ritos de agregação.

A família peregrinou em diferentes solos, até que chegaram a Sítio do Angico, ainda no século XX, povoado localizado em José da Penha, sertão do Rio Grande

NUNES, João Vítor Ferreira. Mas aonde foi parar a santa do sertão, Maria Saldanha?: procura incessante por figuras femininas que acampam um íntimo/mundo imensamente povoado. Revista da FUNDARTE. Montenegro, p.01-15, ano 24, no 43, outubro/dezembro de 2020.

Disponível em: http://.seer.fundarte.rs.gov.br/index.php/revistadafundarte/index $>20$ de dezembro de 2020. 
do Norte. Nas novas terras, Maria, seu filho e seu esposo passaram a residir em uma casa simples, bastante diferente da que nasceu, no entanto, sentia-se feliz por estar distante de qualquer violência física e psicológica ocasionada por homens.

\section{MARIA NAS TERRAS DA MENINA BIA}

Já em Sítio do Angico, RN, Maria Saldanha resolveu ir à igreja, costume esse da infância. No caminho, Bia, ainda menina, a avistou e, rapidamente, se encantou por tamanha beleza da moça. Maria, mulher imensamente educada, cumprimentou a criança e as demais pessoas que estavam a sua volta, apenas com um singelo sorriso. Dali em diante, Bia Mulato passou a admirar uma mulher, e segundo rumores, sonhava em ver a imagem de Maria Saldanha ao se mirar em objetos que refletissem sua aparência.

Entre a casa dos Mulatos e a de Maria Saldanha havia um enorme canavial; sendo, de certo modo, uma grande distância, no mais, não existe distância alguma para quem possui desejos a serem realizados. Bia passava, feito raposa do mato na frente da casa de Maria, para ver sua referência feminina. Seu esposo, o qual desconheciam o nome, logo conseguiu um emprego como motorista de caminhão, passando dias e noites longe de casa, ocupando às estradas de todo o Brasil. Em uma das vezes que o seu cúmplice estava em seu lar, foram os três à casa dos Mulatos para perguntar a Zé; aquele que se considerava o eixo da residência, se uma de suas crias poderia dormir em sua casa, para fazer companhia a sua esposa, a fim de que ela não se sentisse tão solitária. Zé Mulato, então, apontou para Bia como a acompanhante ideal. A menina não conseguiu conter tamanha felicidade e começou a pular por toda residência. Rapidamente, arrumou tudo o que tinha e o que não tinha para ir à casa de Maria, no mais não estava no dia oportuno para a ir pernoitar, pois o marido da moça encontrava-se na residência.

Passaram alguns dias e Maria continuou a frequentar as missas, e todas as vezes cumprimentava a menina Bia, e para ela, ser notada por Maria era um verdadeiro milagre divino. Tenho a precisa intenção de realizar alguns apontamentos

NUNES, João Vítor Ferreira. Mas aonde foi parar a santa do sertão, Maria Saldanha?: procura incessante por figuras femininas que acampam um íntimo/mundo imensamente povoado. Revista da FUNDARTE. Montenegro, p.01-15, ano 24, ํo 43, outubro/dezembro de 2020.

Disponível em: http://.seer.fundarte.rs.gov.br/index.php/revistadafundarte/index $>20$ de dezembro de 2020. 


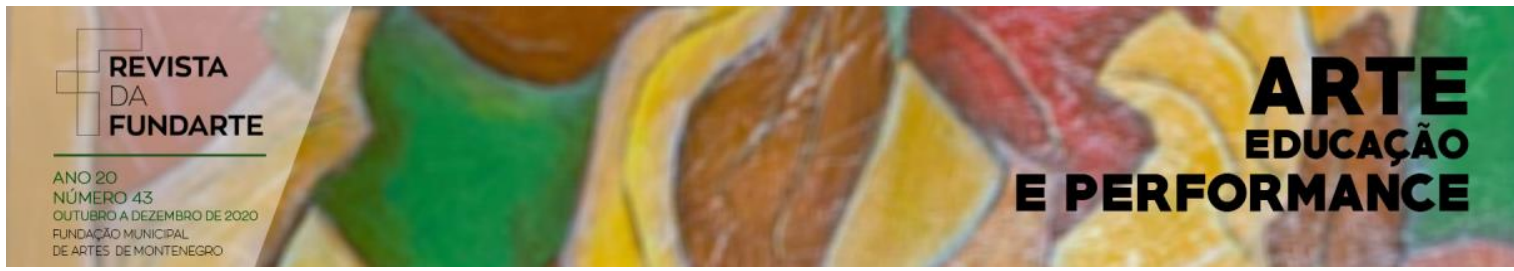

sobre as palavras Milagre e Santa, aqui já mencionadas. Ambas as palavras trazem em seu entorno o cunho religioso propriamente dito, contudo, estamos, a partir deste momento, transitando em solos que evocam sim, a fé humana em algo/alguém, muito embora Maria Saldanha seja vista por alguns, até o presente momento, como indigna de carregar esse título em seu dorso. Infelizmente, o conservadorismo fez pessoas idealizarem tipos de indivíduos dignos de carregar tais palavras aonde fossem.

O povo de Sítio do Angico, ao conhecer Maria Saldanha, passaram a enxergar em suas atitudes semelhanças à Maria mãe de Jesus, tais como amor ao próximo, respeito, bondade, beleza, lealdade e santificação. Porém, antes de tudo isso cair por terra, fora erguido pelo próprio povo, um enorme altar aonde a mesma habitava e era idolatrada, metaforicamente falando. Mas por qual motivo Maria Saldanha carregava tal título em seu dorso? No primeiro momento, por suas atitudes em contexto social, e depois, pelo fato de que, diariamente, ela frequentava a igreja da região em constante oração, utilizando véus sob a cabeça em pleno sol ardente, costume esse da infância. Para, além disso, era considerada uma mulher misteriosa, por ninguém saber do seu passado, nem tão pouco o seu presente, e quando the perguntavam algo que remetesse a isso, rapidamente, ela se retirava dos locais. Devido todo esse conjunto de coisas, conquistou o título de Santa do Sertão, ou Santinha, em Sítio do Angico.

Maria era sim, para o povo antigo daquela região, uma verdadeira beata, e seus rastros sempre foram fáceis de serem seguidos, pelo fato de que ela só saia de casa à igreja, sem desviar os caminhos. Já em sua residência, permanecia com as portas trancadas o dia inteiro.

É difícil ocultar fragmentos de vida desse jeito, mas as mulheres o fazem todos os dias. Quando a mulher se sente obrigada a viver às ocultas, ela está pondo para funcionar um modo de subsistência mínima. Ela oculta a vida para que "eles" não ouçam, quem quer que "eles" sejam na sua vida. Superficialmente, ela aparenta desinteresse e tranquilidade mas, sempre que surge uma réstia de luz, sua alma esfaimada dá um salto, persegue a forma de vida mais próxima, alegra-se, dá coices, avança loucamente, dança como uma boba, fica exausta e depois tenta se esgueirar de volta à

NUNES, João Vítor Ferreira. Mas aonde foi parar a santa do sertão, Maria Saldanha?: procura incessante por figuras femininas que acampam um íntimo/mundo imensamente povoado. Revista da FUNDARTE. Montenegro, p.01-15, ano 24, ํo 43, outubro/dezembro de 2020.

Disponível em: http://.seer.fundarte.rs.gov.br/index.php/revistadafundarte/index $>20$ de dezembro de 2020. 


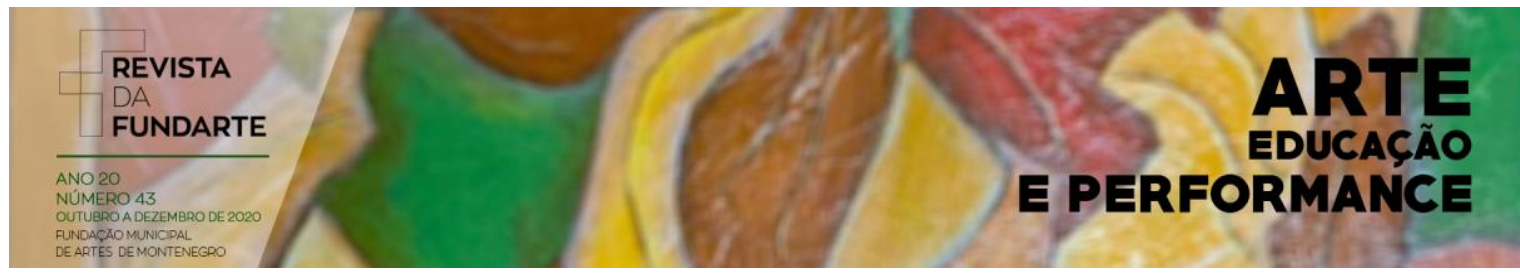

cela sombria antes que alguém perceba sua ausência. As mulheres infelizes no casamento agem assim. As mulheres forçadas a se sentirem inferiores agem assim. As mulheres cheias de vergonha, as que temem ser punidas, expostas ao ridículo ou à humilhação agem assim. As mulheres com instintos feridos agem assim. Esconder o que se faz só é bom para a mulher no cativeiro se ela esconder o que for certo, só se o que ela esconder for exatamente o que a levará à libertação. No fundo, o ato de esconder fragmentos de vida que sejam corajosos, benéficos e que dêem satisfação faz com que a alma fique ainda mais determinada a erradicar a mentira para ter a liberdade de viver a vida abertamente como bem lhe aprouver. (NUNES, 2019, p. 84 apud ESTES, 1994a , p. 178).

Em uma das manhãs, eis que Maria bateu à porta dos Mulatos para dizer que seu esposo tivera partido à trabalho e que, ao anoitecer, Bia fosse para a sua casa pernoitar. Ao receber a notícia no roçado, Bia Mulato começou a trabalhar com enorme entusiasmo, como um alguém cheio de fome frente a um banquete aonde, desesperadamente, devora todo o alimento. Ninguém entendeu o motivo de sua euforia, somente a menina. Antes do pôr do sol, a menina Mulato já se encontrava nas redondezas da casa da mulher misteriosa, completamente suja. Parecia que tinha certeza que na presença da Mulher Santa seria bem cuidada. Nas primeiras horas daquela noite, ela mal falou, na realidade, estava se adaptando ao novo lar noturno. Nas demais, esqueceu que tivera sua própria casa e família.

Foi em pouco tempo que Maria Saldanha começou a enxergar algo positivo na criança, passando a the contar parte de suas histórias. Tornaram-se elas, confidentes. Relatou-me Bia que a cada café da manhã era arrumado um banquete sobre a mesa somente para as duas, contudo, ao passo em que arrumavam a fartura era tanta que parecia que elas iriam receber a visita de outras mulheres. Talvez essas mulheres estivessem sim ao lado delas, emanando forças e transmitindo informações a fim de revigorá-las, bem como dando ouvidos a Maria, enquanto ela abria a boca para partilhar com Bia suas experiências vividas em outros solos, como em Catolé do Rocha. Acredito que toda mulher tem ao seu lado uma força onipresente feminina que fica à espreita, a fim de emanar forças e abrilhantar os caminhos.

NUNES, João Vítor Ferreira. Mas aonde foi parar a santa do sertão, Maria Saldanha?: procura incessante por figuras femininas que acampam um íntimo/mundo imensamente povoado. Revista da FUNDARTE. Montenegro, p.01-15, ano 24, no 43, outubro/dezembro de 2020.

Disponível em: http://.seer.fundarte.rs.gov.br/index.php/revistadafundarte/index> 20 de dezembro de 2020. 


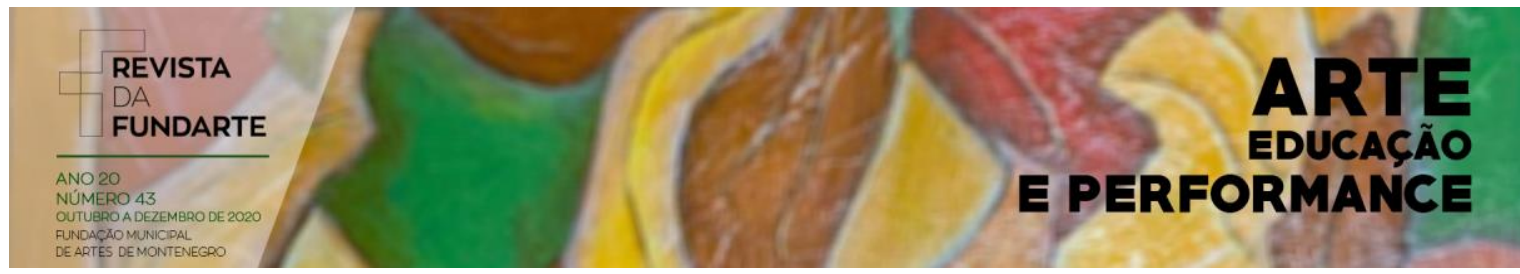

A cada rito partilhado pela Mulher Santa, Bia Mulato começava a compreender os motivos de tanta admiração, amor e afeto para com ela, ou seja, aquilo significava para Bia o quão livre era Maria. Além das histórias, a menina era tão minimalista que passou a observar os detalhes naquela mulher. Vendo-a ainda mais de perto, enxergou tamanha beleza. Ela estava, constantemente, muito arrumada; bem-vestida, portando joias, e com os cabelos sempre com penteados. Era o modelo de pessoa que Bia seguia e queria ser. Parecia ela, uma deusa que foi utilizada como modelo positivo para a criação das esfinges do Egito. A negra santa, Maria Saldanha, nunca foi beatificada, entretanto, aos olhos de boa parte do povoado deveria ter sido... E a devoção à mulher misteriosa era tanta que Bia Mulato passou a pedir forças diariamente, ainda criança, para continuar a seguir em meio a tantas humilhações em sua casa por ser mulher. Com isso, não posso deixar de dizer que até o presente momento, Bia se lembra de Maria Saldanha de forma afetuosa.

Pouco a pouco, Maria foi entregando uma a uma das chaves de seus mistérios a Bia Mulato, e a menina foi se tornando conhecedora desses segredos aos dez anos de idade. Tiveram baús que Maria Saldanha demorou um pouco mais a abrir, e somente após um tempo dessa amizade, a mulher misteriosa passou a sentir mais confiança na criança, contando, assim, novos ritos.

\begin{abstract}
Nas histórias, a dupla da mais nova e da mais velha juntas assume a missão de dar muitas bênçãos necessárias uma à outra para seguir adiante, sair-se bem, ser corajosa e audaz, e levar o tipo de vida na qual as almas são bem-nutridas. Por que os atributos da mulher sábia são, além disso, tão importantes para as jovens? E por que a sabedoria e a energia das jovens são tão importantes para as mais velhas? Juntas, elas simbolizam dois aspectos essenciais encontrados na psique de cada mulher. Pois a alma de uma mulher é mais velha que o tempo, e seu espírito é eternamente jovem... sendo que a união desses dois compõe o - ser jovem enquanto velha e velha enquanto jovem. (ESTES, 2007b, p. $20-21$ ).
\end{abstract}

Havia algo que Bia não compreendia naquele lar, sendo o fato de Maria lhe trancafiar em um dos cômodos da casa. Em uma das várias noites, quando já trancada em um dos quartos, a menina foi pega pela insônia. Ela virava para um

NUNES, João Vítor Ferreira. Mas aonde foi parar a santa do sertão, Maria Saldanha?: procura incessante por figuras femininas que acampam um íntimo/mundo imensamente povoado. Revista da FUNDARTE. Montenegro, p.01-15, ano 24, № 43, outubro/dezembro de 2020.

Disponível em: http://.seer.fundarte.rs.gov.br/index.php/revistadafundarte/index $>20$ de dezembro de 2020. 
lado, virava para o outro, e nada de dormir. Após um tempo rolando pela cama, eis que Bia escutou sons no interior da casa; sons estes que ela nunca tivera ouvido antes, e que não conseguia fazer comparativos a coisas já conhecida. Movida pela curiosidade, levantou-se da cama e começou a se aproximar da porta do quarto. $\mathrm{E}$, ao passo que se aproximava, os barulhos só aumentavam. Curiosa para saber o que estava acontecendo, olhou pelas frestas da porta falha e, de dois a três minutos curiando, enxergou vultos, um correndo e outro andando de forma acelerada. Assustada com o que fora visto, pulou de volta na cama e cobriu-se dos pés à cabeça com o cobertor.

Amedrontada por não ter entendido o que tivera visto, Bia mal conseguiu dormir. Ao amanhecer, latejava em seu imaginário o que poderia ser aqueles vultos. $\mathrm{Na}$ hora do banquete matinal, eis o momento de compartilhar à notícia. Ela direcionou um questionamento a Maria Saldanha de forma direta, perguntando se ela também havia escutado barulhos estranhos durante à noite. Maria disse que não, e a menina começou a detalhar para a mulher santa o que tivera ouvido e observado. E mais uma vez Maria disse não ter ouvido nada. Bia, no intuito de proteger Maria, aprofundou-se no assunto e afirmou ter visto algo estranho rondando o interior da casa, e que suspeitava que fossem os espíritos de pessoas mortas. Carregando em sua face um sorriso envergonhado, Maria Saldanha, sem muita rodagem, entregou a última chave do baú de seus mistérios para a menina, contando, sem muitos detalhes, o que acontecia naquela casa todas as noites, dizendo:

- Bia, tu não podes contar a ninguém o que eu vou te dizer... é mais um segredo nosso. Aquilo que tu avistaste não eram fantasmas, era um amigo meu. Bia, eu sou uma Rapariga!!! Por isso que eu sou tão bonita no mundo, e vivo arrumada. Aquele amigo sempre vem a minha casa me visitar... vem ele e outros, tantos outros, mas lembre-se, tu não podes contar para ninguém.

\section{E a garota perguntou:}

NUNES, João Vítor Ferreira. Mas aonde foi parar a santa do sertão, Maria Saldanha?: procura incessante por figuras femininas que acampam um íntimo/mundo imensamente povoado. Revista da FUNDARTE. Montenegro, p.01-15, ano 24, no 43, outubro/dezembro de 2020.

Disponível em: http://.seer.fundarte.rs.gov.br/index.php/revistadafundarte/index $>20$ de dezembro de 2020. 


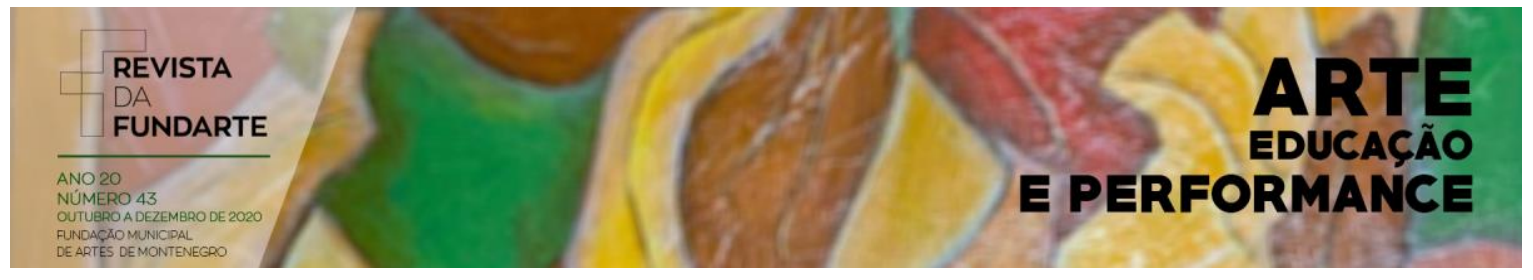

- Maria, é bom ser uma rapariga?

- É Sim, Bia. É maravilhoso!!!

- Mas por que tu és rapariga, Maria?

Certa de sua resposta, a mulher considerada a santa do povoado respondeu:

- Por que eu não gosto de ficar e, principalmente, de dormir só, Bia. Só por isso...

Olhando para o horizonte, com um sorriso estampado em seu rosto, Bia falou:

- Quando eu crescer, Maria, eu vou ser uma Rapariga igual a você; vou viver muito arrumada, serei muito bonita. Vou ter muitos amigos e todo mundo vai gostar de mim!!!

- Seja sim Bia, você vai ser a mulher mais feliz deste mundo!

Feliz por ter traçado um destino a partir do contato com Maria Saldanha, a menina correu para a sua casa como se estivesse ventando o mundo e cortando o ar. Ao chegar, seus irmãos notaram a felicidade no rosto da criança, e perguntaram o porquê de tamanha alegria. Percebendo que todos da casa estavam juntos à mesa, justamente por conta do almoço, ela pegou o banco que lhe sobrava, subiu, como se estivesse em um púlpito e disse em alto e em bom tom, que ao crescer seria como Maria Saldanha e não como sua mãe, que era maltratada em casa:

- Quando eu crescer, não serei como mamãe, que não se arruma e que muito trabalha em casa. Eu vou ser como Maria Saldanha, muito bonita, arrumada e com muitos amigos. Eu vou ser uma R A P A R I G A!!!

Sorrindo incontrolavelmente, Bia Mulato observou como todos os seus familiares haviam ficado perplexos com o que ela tivera dito. Na verdade, ela sorria

NUNES, João Vítor Ferreira. Mas aonde foi parar a santa do sertão, Maria Saldanha?: procura incessante por figuras femininas que acampam um íntimo/mundo imensamente povoado. Revista da FUNDARTE. Montenegro, p.01-15, ano 24, no 43, outubro/dezembro de 2020.

Disponível em: http://.seer.fundarte.rs.gov.br/index.php/revistadafundarte/index> 20 de dezembro de 2020. 


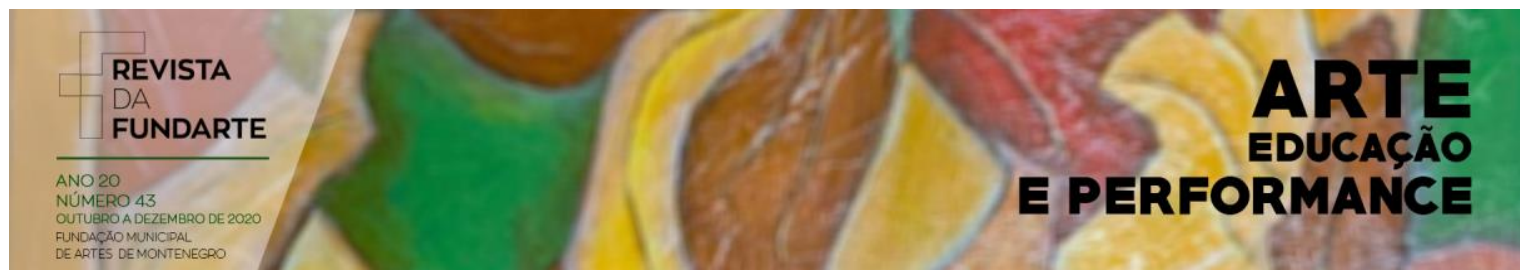

por crer que se encontrava em um lugar de admiração, entretanto devido a sua inocência da infância, não fazia ideia do peso de suas palavras para os conservadores. Ao dizer que seria uma rapariga, acabara por ser marcada como uma pessoa que em um futuro breve não seria digna de respeito; aos olhos dos outros. Naquele mesmo instante, rapidamente, o seu pai levantou-se da mesa e se agarrou, com as duas mãos, em seus longos cabelos cacheados, arrastando-a por toda casa, até o terreiro. Chegando lá fora, atirou a menina ao chão. Em instantes, formou-se uma enorme plateia para ver Bia ser agredida verbalmente e fisicamente. Indefesa daquela força brutal, recebeu duras palmadas, seguidas de palavras carregadas de ódio. A surra teve duração de três a quatro minutos, até que a menina urinou e defecou na roupa. Mencionando novamente os estudos de Foucault nesse artigo, ainda sobre o termo Teatro dos Castigos, exponho:

\begin{abstract}
Eis então como devemos imaginar a cidade punitiva. Nas encruzilhadas, nos jardins, à beira das estradas que são refeitas ou das pontes que são construídas, em oficinas abertas a todos, no fundo de minas que serão visitadas, mil pequenos teatros de castigos. Para cada crime, sua lei; para cada criminoso, sua pena. Pena visível, pena loquaz, que diz tudo, que explica, se justifica, convence: placas, bonés, cartazes, tabuletas, símbolos, textos lidos ou impressos, isso tudo repete incansavelmente o Código. Cenários, perspectivas, efeitos de ótica, fachadas às vezes ampliam a cena, tornam-na mais temível, mas também mais clara. Do lugar onde está colocado o público, poder-se-ia acreditar em certas crueldades [...]. Mas o essencial, para essas severidades reais ou ampliadas, é que [...] todas elas sirvam de lição: que cada castigo seja um apólogo. E que, em contraponto a todos os exemplos diretos de virtude, se possam a cada instante encontrar, como uma cena viva, as desgraças do vício. Em torno de cada uma dessas "representações" morais, os escolares se comprimirão com seus professores e os adultos aprenderão que lição ensinar aos filhos. Não mais o grande ritual aterrorizante dos suplícios, mas no correr dos dias e pelas ruas esse teatro sério, com suas cenas múltiplas e persuasivas. E a memória popular reproduzirá em seus boatos o discurso austero da lei. (p. $132-133)$.
\end{abstract}

Aquele homem feroz, só parou de bater na criança ao se cansar. Em seguida, ainda movido pela fúria, exigiu que, rapidamente, ela se limpasse, pois encontravase na hora dela, sozinha e sem almoçar, voltar ao campo. Ao longo de sua vida no sertão, Bia não mais saiu da roça. Dentre às punições já recebidas acerca de sua

NUNES, João Vítor Ferreira. Mas aonde foi parar a santa do sertão, Maria Saldanha?: procura incessante por figuras femininas que acampam um íntimo/mundo imensamente povoado. Revista da FUNDARTE. Montenegro, p.01-15, ano 24, oㅡ 43, outubro/dezembro de 2020.

Disponível em: http://.seer.fundarte.rs.gov.br/index.php/revistadafundarte/index $>20$ de dezembro de 2020. 


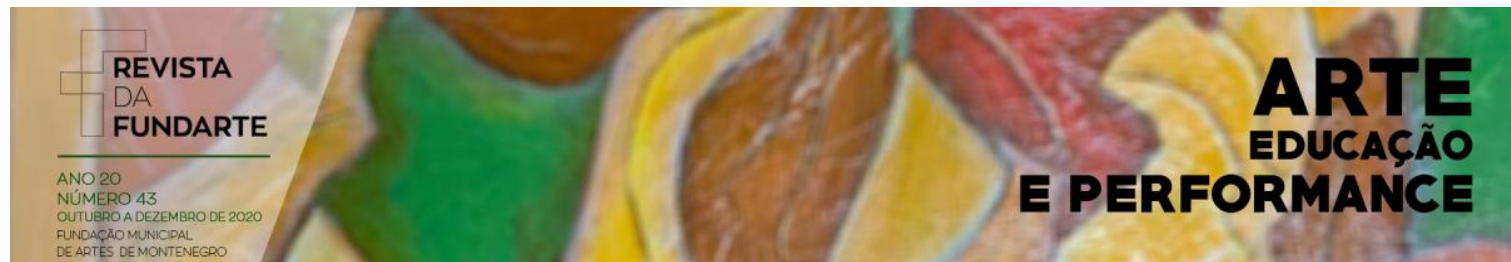

"má-educação", em ousar ser livre, aquela foi, aos olhos de todos; irmãos e irmãs, incluindo sua mãe, Chiquinha Mulato, a pior de todas. Devido aquele episódio, Bia ficou marcada de forma negativa por todos os familiares, e isso se perdura até o presente momento, por ter dito que seria uma rapariga ao crescer. Percebo que ela não teve culpa, mas sim Maria Saldanha, por não ter detalhado a história. A falta de informação fez Bia abrir a boca para todos a sua volta, e ela passou um longo tempo de sua vida sem entender o que tivera dito de errado, a ponto de merecer tamanha brutalidade.

Por mais que ela tenha sofrido mutilações profundas, sua raiz radiante ainda está viva, ainda está produzindo e sempre estará à procura da vida significativa a céu aberto. Essa força interna é cheia do impulso pelo bemestar. Ela acredita num fator de salvação que pode resistir e há de resistir à crueldade. (ESTES, 2007b, p. $40-41$ ).

Em contato com Bia já idosa, ela revelou que achava que uma rapariga era uma mulher que se arrumava, se pintava e que era muito bonita, amada e admirada por todos, como de fato ela via Maria Saldanha ser tratada. À vista disso, "há uma classe social interessada em que as coisas permaneçam como estão, e que a verdade sobre suas motivações mais profundas não seja dita" (DESPENTES, 2016, p. 91), e talvez esse tenha sido o motivo de Maria ter poupado a menina de tantos detalhes. Embora tenha sofrido algumas lesões, Bia não desviou seu olhar para o que ainda não enxergava no horizonte. Mesmo não tendo certeza da vida, ela já havia traçado o seu destino, de ser como Maria Saldanha.

Mesmo sem uma mentora como Bia, Maria, em sua juventude, escolheu traçar seu próprio destino, desviando-se com maestria de toda educação machista que seus familiares lhe tentaram enfiar goela abaixo. Ousou em ser uma rapariga em pleno sertão e, assumindo essa postura, foi expulsa do seio familiar.

Após a menina Bia ter sido agredida em sua casa, o maior segredo de Maria Saldanha; de que ela era uma prostituta, foi espalhado no povoado feito peste, e os contadores desse boato foram os próprios Mulatos, irmãos de Bia, mesmo sendo alguns deles seus confidentes. Não posso deixar de dizer que a única referência de

NUNES, João Vítor Ferreira. Mas aonde foi parar a santa do sertão, Maria Saldanha?: procura incessante por figuras femininas que acampam um íntimo/mundo imensamente povoado. Revista da FUNDARTE. Montenegro, p.01-15, ano 24, no 43, outubro/dezembro de 2020.

Disponível em: http://.seer.fundarte.rs.gov.br/index.php/revistadafundarte/index $>20$ de dezembro de 2020. 


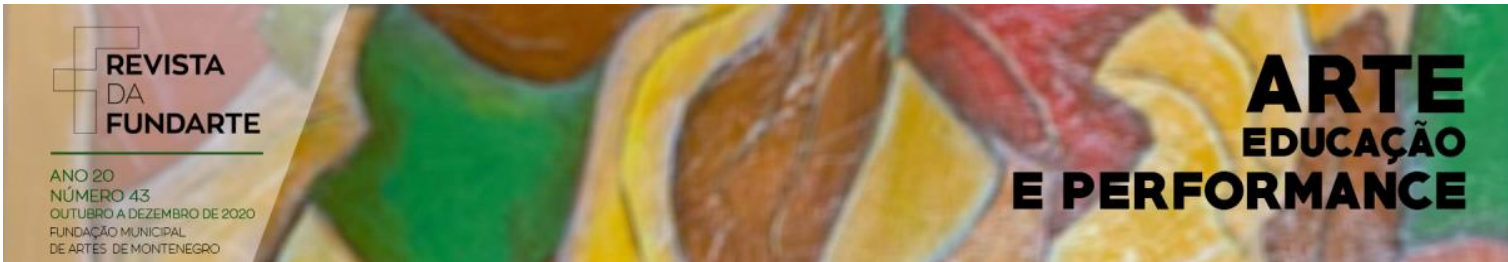

mulher livre que Bia Mulato teve ao longo de sua vida, foi uma meretriz. Um ser que ultrapassou as fronteiras do machismo e que viveu sua vida como tinha desejo. Nem mesmo sua mãe lhe inspirou a ser uma mulher de verdade, pois para Bia, ser uma mulher de verdade era ser como Maria Saldanha; fazer suas próprias escolhas, sem viver golpeada pelo machismo. Era emanar liberdade.

Após os boatos terem sido espalhados, o enorme pedestal ou, talvez, o altar, erguido pelo povo de Sítio do Angico para a Santa misteriosa, tivera sido depredado e, aos poucos, fora demolido. Ela nunca soube o verdadeiro motivo de terem corrido com a notícia, que, segundos os Mulatos, fora justamente por ela ter "influenciado" uma criança a seguir seus rastros. Todo povo passou a compreender os motivos de Maria desviar tanto de suas histórias. Na verdade, o que ela evitava, era que as pessoas descobrissem quais desejos the moviam. Passaram a dizer que ela ia à igreja retirar os inúmeros pecados, para logo mais colocá-los novamente, mas que Deus nunca ia ter misericórdia de mulheres como ela.

A partir disso, Maria ficou ainda mais trancafiada em seu lar. O que era visto pelos frequentadores como o "parque de diversão noturno do sertão"; como assim ficou conhecida no povoado, tivera fechado suas portas por toda eternidade. Dali em diante, veio à tona a proibição da amizade entre Bia e Maria: o espelho foi quebrado e o contato entre o mundo místico e o real passou a ser limitado. Com o espelho estilhaçado, a criança se viu desfigurada, e a única força que passou a erguer Bia, frente às inúmeras violências vinham das sementes plantadas em seu jardim secreto; seu interior, por Maria Saldanha.

[...] no meio de qualquer tempestade ou contentamento, a bela força da vida estará para sempre preservada pela mulher oculta, que sempre se esforçará para que saiba que consertos e impulsos começam novamente no próprio momento em que somos destruídas. Assim, essa força interior atua como [...] a essência da santidade e da sabedoria da alma que sempre nos guia e que jamais nos abandonará. (ESTES, 2007º, p. 46).

Como Bia Mulato não sabia quais as práticas de uma rapariga, aos poucos suas irmãs mais velhas foram lhe contando. Após as trocas de informações, Bia

NUNES, João Vítor Ferreira. Mas aonde foi parar a santa do sertão, Maria Saldanha?: procura incessante por figuras femininas que acampam um íntimo/mundo imensamente povoado. Revista da FUNDARTE. Montenegro, p.01-15, ano 24, no 43, outubro/dezembro de 2020.

Disponível em: http://.seer.fundarte.rs.gov.br/index.php/revistadafundarte/index> 20 de dezembro de 2020. 


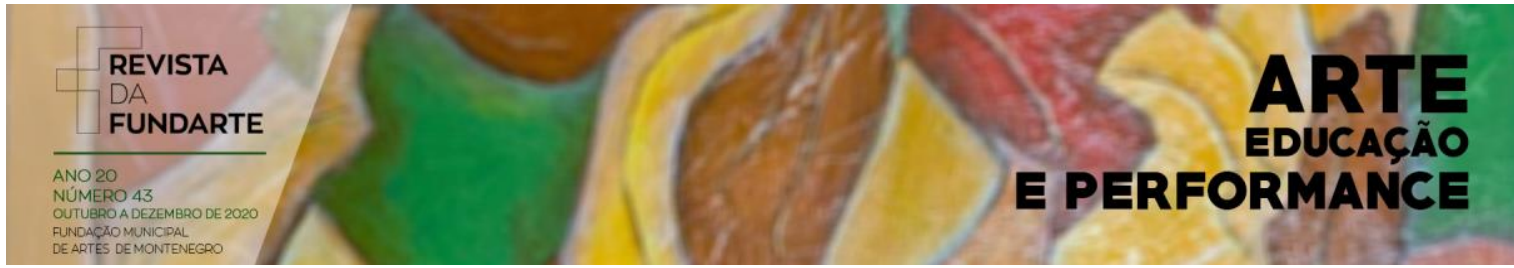

ainda se sentiu nutrida pelo sonho de ser como Maria Saldanha, já que aquilo fazia com que seu pai criasse, de certo modo, uma raiva dela e da mulher não mais Santa. Ela causou ainda mais desconfortos entre os familiares ao dizer que mesmo apanhando, seguiria sim, os rastros da santa profana.

\begin{abstract}
À medida que uma mulher cresce a céu aberto na realidade consensual, ela também ordena a expansão do sistema radicular para que sua visão profunda, a audição mais cuidadosa e a mente mais perspicaz também se expandam. Trata-se de um processo de série, atemporal, sagrado, acionado pela atenção consciente ao modo pelo qual a psique amadurece de uma jovem menina para uma sábia vibrante, dançante, aprimorada pelo tempo (ESTES, 2007b p. 44).
\end{abstract}

Fogo ardente, desejos no coração, os tempos foram passando e a força daquela mulher misteriosa ainda estava latente nos caminhos de Bia Mulato. Percebo, também, que a força que atuava entorno de Bia, não mais criança e sim recém-moça, não vinha somente de Maria Saldanha, mas também de tantas outras mulheres que a espreitavam. Mulheres estas que Bia e nós, não vemos a olho nu. É necessário que fechemos os olhos e nos conectemos com a natureza a nossa volta.

Mesmo proibida de manter contato com Maria Saldanha, vez ou outra, a moça ia à casa da mulher não mais misteriosa e santa. Recebida por afetos, Bia permanecia longos períodos em sua companhia, e elas conversavam sobre todas as coisas. A menina-moça então partilhou algumas novidades, dentre elas a suposta proibição da amizade e que sentia muito sua falta, e por esse motivo é que foi visitála. Falou também que estava frequentando a escola, às escondidas. Maria Saldanha disse para Bia tomar muito cuidado nas idas à sua casa, e que pra evitar de ser pega, que sempre fosse pelo canavial e entrasse e saísse pelas portas dos fundos, pois assim ninguém a veria, e que continuasse buscando sua independência, mesmo sofrendo algumas punições físicas, pois um dia havia de aparecer uma salvação.

NUNES, João Vítor Ferreira. Mas aonde foi parar a santa do sertão, Maria Saldanha?: procura incessante por figuras femininas que acampam um íntimo/mundo imensamente povoado. Revista da FUNDARTE. Montenegro, p.01-15, ano 24, ํo 43, outubro/dezembro de 2020.

Disponível em: http://.seer.fundarte.rs.gov.br/index.php/revistadafundarte/index $>20$ de dezembro de 2020. 
Logo, ocorreram alguns episódios que levaram Bia a sair de Sítio do Angico, expulsa feito o demo, tal como aconteceu em tempos anteriores com a Santa do Sertão, Maria Saldanha. Episódios esses, aonde os homens da família Mulato a colocaram em praça pública e agrediram aquele corpo, utilizando-a, mais uma vez, como modelo negativo, como nos aponta Foucault, pelo fato dela se relacionar amorosamente com vários homens. De longe, Maria Saldanha avistou sua amiga ser agredida na frente de toda cidade. Após o atentado, Bia pegou carona no primeiro pau de arara que viu pela frente, e começou a desbravar o mundo, em busca de braços confiáveis. Chegou à Natal, capital de seu estado, e lá tocou sua vida para frente como tinha desejo. Em um curto espaço de tempo, ela se transformou em uma grande artista noturna, cantando e encantando os bordéis da cidade em plena segunda guerra mundial.

Cara leitora, Bia Mulato, que por um acaso da vida é a minha avó materna, não soube me dizer com tanta certeza o que aconteceu, de fato, com a Santa do Sertão, Maria Saldanha, logo após sua expulsão de Sítio do Angico, nem tão pouco o povo da cidade soube falar sobre o sumiço de Maria. Na busca por informações, descobri que a corja dos Mulatos foi até a casa da Santa e começaram a gritar palavras ofensivas, dizendo que foi ela a grande responsável por tudo que aconteceu com Bia. Mas, antes deles chegarem à residência da mulher, Maria com seu filho nos braços, saiu mundo afora por puro medo. Parecia que estava adivinhando o que poderia acontecer com ela, ao ver aquela triste cena acontecendo com Bia. Seu marido, por sua vez, também nunca mais fora visto por Sítio do Angico.

Pela segunda vez na vida, Maria Saldanha foi expulsa de um lugar. Depois daquele dia, ninguém, nunca mais, teve qualquer notícia dela, pois sumiu no mundo, e assim esperamos, Bia e eu, que ela tenha encontrado o lugar místico que a autora Clarissa Pinkola Estés nos apresenta em seu livro Mulheres que correm com os lobos (1994ª), onde os humanos são tão bons como maus, onde os animais ainda

NUNES, João Vítor Ferreira. Mas aonde foi parar a santa do sertão, Maria Saldanha?: procura incessante por figuras femininas que acampam um íntimo/mundo imensamente povoado. Revista da FUNDARTE. Montenegro, p.01-15, ano 24, no 43, outubro/dezembro de 2020.

Disponível em: http://.seer.fundarte.rs.gov.br/index.php/revistadafundarte/index $>20$ de dezembro de 2020. 
dançam com muita liberdade, onde as flores ainda sorriem para nós. O fato é que ninguém sabe aonde foi parar Maria Saldanha, além de dentro de Bia Mulato. Seguimos em uma incessante busca por essa mulher, que bravamente guerreou contra o sistema patriarcal e misógino em pleno século XX para se tornar livre, no sertão nordestino. Caso vocês saibam, leitoras, entrem em contato comigo, de alguma forma, pois necessito fazer com que Bia encontre sua grande amiga.

\section{CONSIDERAÇÕES FINAIS: A FRICÇÃO ENTRE A FIGURA DE MARIA E A} ÂNIMA CRIATIVA DESEMBOCADA NUMA COMUNICAÇÃO PERFORMTIVA

A partir das informações que obtive com relação à pesquisa de campo realizada, entre 2017 e 2019, partimos, eu e Luciana Lyra; ela como mediadora, para as salas de ensaios em busca de figuras femininas que habitam as entranhas de minh'alma. Estávamos em busca da Maria Saldanha e da Bia Mulato, que viviam em meu íntimo, acessando as camadas profundas de meu inconsciente, através dos procedimentos míticos e ritualísticos da Mitodologia em Arte. Para ser mais preciso, realizei imersões na alquimia dos elementos: água, ar, fogo e terra, para assim avistar as sendas de criações artísticas, em uma constante relação com minha ânima criativa. Nessa busca, vi que em meu íntimo há inúmeras figuras femininas, santas e profanas, bem como livres e felizes, espelhadas em Maria e Bia. O influxo que resultou na aparição das figuras Femininas, através de meu corpo via artes da cena, partiu dos estudos da Profa ${ }^{-}$Ph.D. Luciana Lyra.

A Mitodologia em Arte, bem como a Jornada Artetnográfica, faz-se elo entre Vida e Arte, e assim fui diretamente conduzido, ao longo do processo criativo, por um modus operandi de criação cênica, cujo objetivo é fazer com que os artistas lidem com suas forças pessoais, bem como com aquilo que lhe faz mover.

Dessa maneira, mergulhei a fundo nas camadas de meu inconsciente à conscientização e avistei potências oriundas do contato direto com minha feminilidade interior, chamada de energia ânima, que, segundo o psiquiatra suíço Carl Gustav Jung (2000), nada mais é do que imagens arquetípicas que encontram-

NUNES, João Vítor Ferreira. Mas aonde foi parar a santa do sertão, Maria Saldanha?: procura incessante por figuras femininas que acampam um íntimo/mundo imensamente povoado. Revista da FUNDARTE. Montenegro, p.01-15, ano 24, № 43, outubro/dezembro de 2020.

Disponível em: http://.seer.fundarte.rs.gov.br/index.php/revistadafundarte/index $>20$ de dezembro de 2020. 


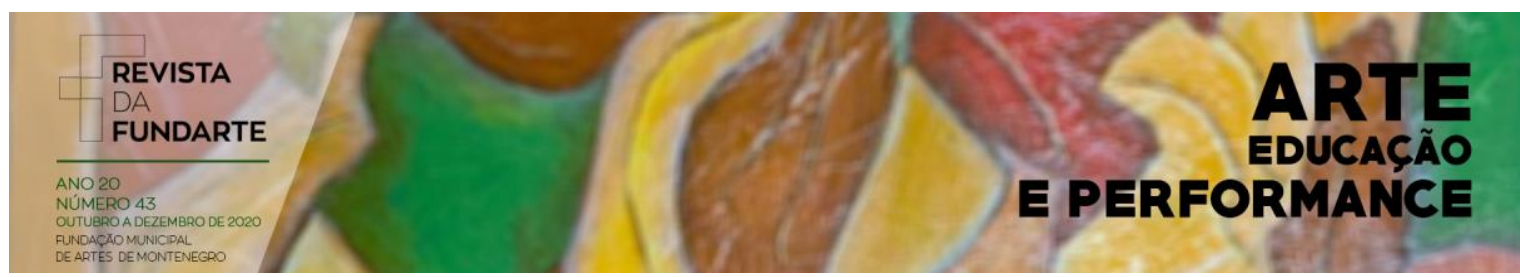

se alocadas em nosso íntimo, e fazem parte da essência de nossa alma, atuando fortemente em nossa personalidade. Foi na seara das artes da cena, atrelada a uma pesquisa de campo chamada de artetnografia e nos deleites dos procedimentos da mitodologia em arte que realizei essa pesquisa, chegando a resultados teóricos e práticos. Portanto, estou integrado às proposições junguianas desde 2013, dialogando acerca de vidas femininas, atrelando aos entendimentos sobre arquétipos, mitos, ego, sombra, feminilidade, em um constante estado de individuação. Neste conjunto, permito ser impulsionado, mesmo que pelo caos, para que eu possa, de alguma forma, avançar em empreitadas acadêmicas como essa, de mãos dadas com minhas antepassadas. Nessa busca, pude conhecer Bia, minha avó criança, bem como sua mentora, Maria Saldanha, a Santa do Sertão, e ambas as mulheres resistiram bravamente em meio a tantos episódios de violência contra seus corpos femininos.

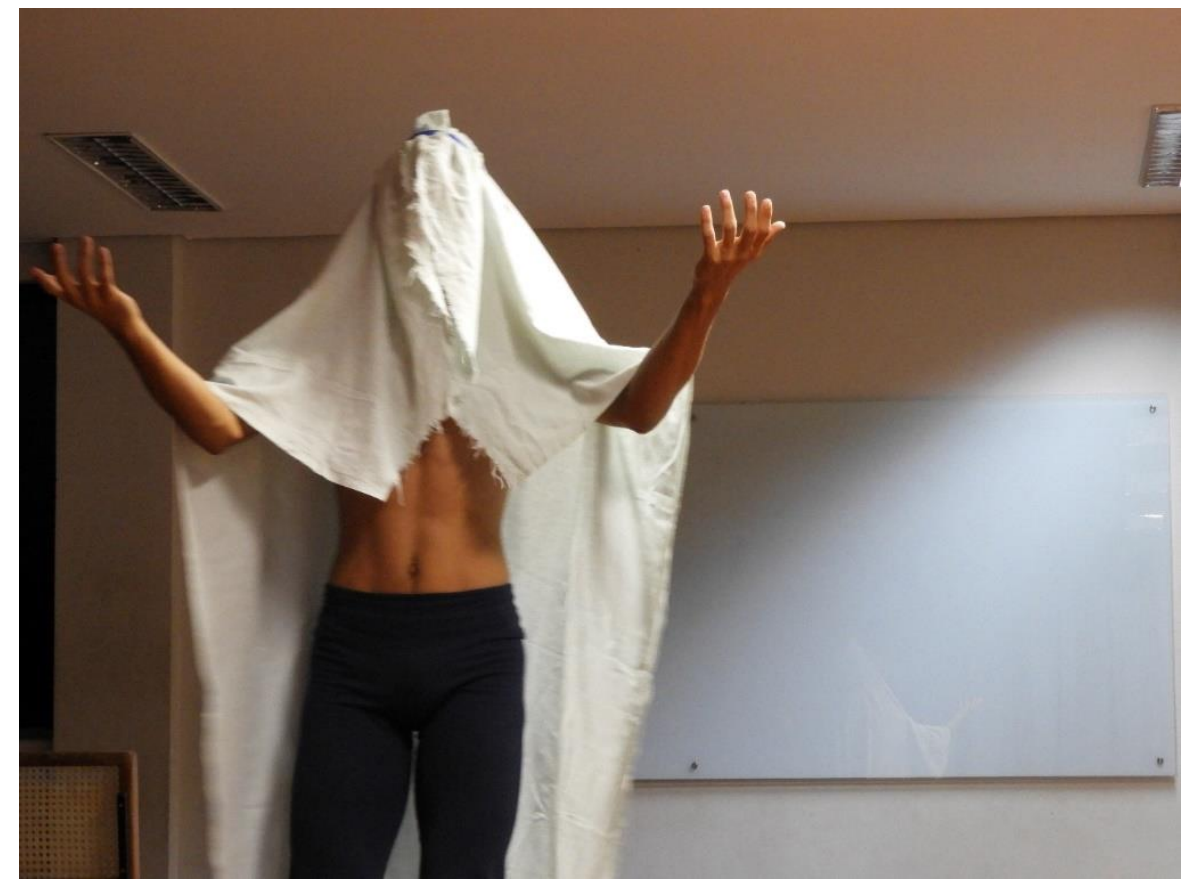

Figura 1 - Maria Saldanha em cena, no processo performático BIA-BOA (2019)

Ao longo deste estudo, acampamos na história de Maria Saldanha, e de forma breve, na de Bia Mulato, e vimos o quanto as mulheres são silenciadas e/ou

NUNES, João Vítor Ferreira. Mas aonde foi parar a santa do sertão, Maria Saldanha?: procura incessante por figuras femininas que acampam um íntimo/mundo imensamente povoado. Revista da FUNDARTE. Montenegro, p.01-15, ano 24, nํ 43, outubro/dezembro de 2020.

Disponível em: http://.seer.fundarte.rs.gov.br/index.php/revistadafundarte/index $>20$ de dezembro de 2020. 


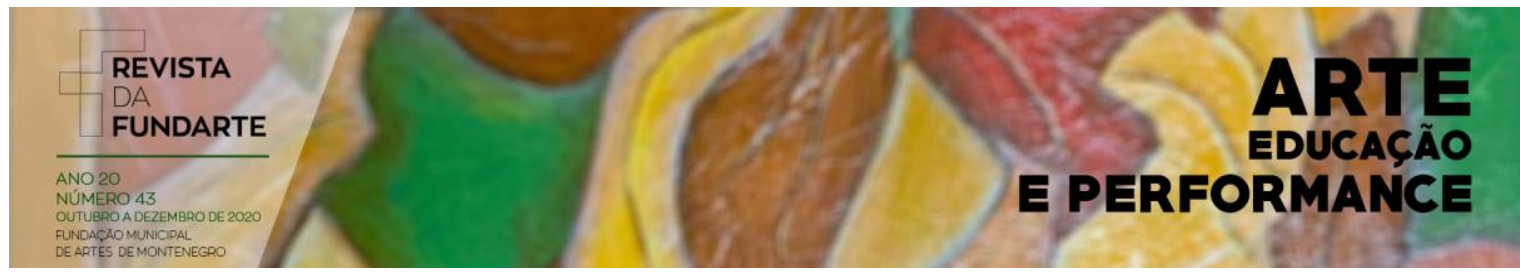

esquecidas, colocadas em um traçado de inferioridade por serem mulheres, principalmente, se elas rompem com os padrões impostos e buscam por sua liberdade. Sigo realizando estudos na seara das artes da cena, onde tenho por objetivo protagonizar ritos femininos que foram silenciados, esquecidos, subalternizados. Busco valorizar, desta maneira, minhas ancestrais, e que muito resistiram ao longo dos tempos, e talvez a arte seja isso: revelar, a cada empreitada, novos elementos que nos levam a nós mesmos, seja o feminino, histórias de mulheres ou nossa ânima.

\section{Referências:}

DESPENTES, V. Teoria King Kong. São Paulo: n-1 edições, 2016.

ESTES, C. P. Mulheres que correm com os lobos: mitos e histórias do arquétipo da mulher selvagem. Rio de Janeiro: Rocco, 1994ª

ESTES, C. P. A ciranda das mulheres sábias: ser jovem enquanto velha, velha enquanto jovem. Rio de Janeiro: Rocco, 2007b.

FOUCAULT, Michel. Vigiar e Punir: nascimento da prisão. Petrópolis: Vozes, 1987.

GENNEP, A. Os Ritos de Passagem. Petrópolis: Vozes, 2011.

JUNG, C. G. Os arquétipos e o inconsciente coletivo. Petrópolis: Vozes, 2000.

LYRA, L. F. R. P. Caboclos, guerreiras, artistas de $f(r)$ icção: cravos e pérolas d'alma. Urdimento, v.2, n. 25, p. 72-83, 2015.

NUNES, J. V. F. A Força e a Chuva Feminina em um Sertão bem masculino: imersão performática nos Ritos de Passagem de Bia Mulato pela Mitodologia em Arte. Natal, 2019. Dissertação (Mestrado em Artes Cênicas) - Departamento de Artes, Universidade Federal do Rio Grande do Norte.

TURNER, V. Floresta de Símbolos: aspectos do ritual Ndembu. Rio de Janeiro: Niterói, 2005.

NUNES, João Vítor Ferreira. Mas aonde foi parar a santa do sertão, Maria Saldanha?: procura incessante por figuras femininas que acampam um íntimo/mundo imensamente povoado. Revista da FUNDARTE. Montenegro, p.01-15, ano 24, no 43, outubro/dezembro de 2020.

Disponível em: http://.seer.fundarte.rs.gov.br/index.php/revistadafundarte/index $>20$ de dezembro de 2020. 